\title{
Genetic Variation in Early Growth and Bud Production among Natural Populations of Fraser Fir
}

\author{
Jennifer L. Emerson ${ }^{1,4}$, John Frampton ${ }^{2}$, and Steven E. McKeand ${ }^{3}$ \\ North Carolina State University, Department of Forestry and Environmental \\ Resources, Campus Box 8008, Raleigh, NC 27695
}

Additional index words. Abies fraseri, heritability, Christmas tree, tree improvement, geographic variation

\begin{abstract}
A series of open-pollinated progeny tests of Fraser fir [Abies fraseri (Pursh) Poir.] was analyzed to determine natural variation among six geographic seed sources and to estimate genetic parameters for traits important in Christmas tree production. Highly significant differences were found among seed sources and families within sources $(P \leq 0.0001)$ for height after 4 years in the field. The individual-tree within-population heritability values for the traits measured in Year 4 ranged from 0 to 0.44 , with height having the highest heritability, overall tree quality having a heritability of 0.14 , and bud and branching traits having varying heritabilities. Heritability values for height at age 4 varied greatly among the six sources, from 0.15 for the Black Mountains to 0.67 for the Great Smoky Mountains. Highly significant seed source $\times$ site interactions as well as family within source $\times$ site interactions existed for height. Stability variance analysis, after removing the environmental heterogeneity, showed significant instability across the test sites for two of the six seed sources for height after 4 years, and some rank changes occurred. The high heritability values for height indicate that economically important genetic gains can be made in Fraser fir for Christmas tree production because of the importance of height in determining Christmas tree value.
\end{abstract}

Fraser fir (Abies fraseri) is the only fir species native to the southern United States, and it is found naturally only in a few stands at elevations of about $1300 \mathrm{~m}$ to over $2000 \mathrm{~m}$ in western North Carolina, eastern Tennessee, and southwestern Virginia (Dull et al., 1988). These forests are associated with important scenic and recreational areas, such as the Great Smoky Mountains National Park, Mount Mitchell State Park, the Balsam Mountains, and the Mount Rogers National Recreation Area (Dull et al., 1988). In addition to its recreational and ecological importance, Fraser fir also holds great economic importance as a Christmas tree species. It is grown in plantations as Christmas trees

Received for publication 5 Oct. 2007. Accepted for publication 6 Jan. 2008

We thank the Christmas tree growers who maintained these progeny tests: Wilson Barr, Thomas Beutell, Mark Cody, J.B. Greene, Dan McKinney, James Pitts, Jerry Wilson, and Johnny Wishon. We acknowledge the North Carolina Division of Forest Resources, especially Joe Shoupe, for their work in culturing the seedlings in the nursery. We also thank AnneMargaret Braham, Jianfeng Li, and the rest of the Christmas Tree Genetics program for their technical support as well as J.B. Jett and Fred Hain for their review of previous drafts of this paper.

${ }^{1}$ Graduate Research Assistant.

${ }^{2}$ Professor.

${ }^{3}$ Professor and Co-Director of the NCSU Tree Improvement Cooperative.

${ }^{4}$ To whom reprint requests should be addressed; e-mail jlemerson@ncsu.edu throughout the southern Appalachians as well as other areas of the United States. It is a premier Christmas tree species because of its aroma, blue-green color, conical shape, and excellent post-harvest foliage retention.

Natural Fraser fir populations have declined severely in the last 50 years, with most mature trees being eliminated. This decline has been due mainly to the balsam woolly adelgid (formerly balsam woolly aphid) (Adelges piceae Ratzeburg), an insect accidentally introduced from Europe. Fraser fir trees on Mount Mitchell in the southern Appalachians were found to be infested with the balsam woolly adelgid by 1957 , and since then the insect has spread throughout the entire range of Fraser fir (Dull et al., 1988; Speers, 1958). Fraser fir has been shown to be one of the most susceptible of the North American fir species to balsam woolly adelgid infestation, with trees often being killed (Mitchell, 1966). By 1966, there was $95 \%$ to $98 \%$ Fraser fir mortality in the Mount Mitchell area in North Carolina (Witter and Ragenovich, 1986)

Information about the genetic variation of Fraser fir in natural stands is necessary to conserve its genetic diversity in the face of this ecological threat and to make improvements for Christmas tree production. One previous provenance-progeny test series of Fraser fir established in 1983 found significant differences among sources and among families within seed sources for all traits measured (Arnold and Jett, 1995; Arnold et al., 1994b; Jett et al., 1993). Heritabilities for most traits important in Christmas trees were strong enough to show potential for gain through selection and breeding (Arnold et al., 1994b). In 1992, following the eighth-year assessment, over 170 selections from this test series were grafted into a clone bank for advanced generation breeding and genetic conservation. In 2000, regional Christmas tree growers established a clonal seed orchard using 30 of the best selections.

The prior test series evaluated a limited number of seed sources on only three sites, so more thorough testing of a greater number of families from throughout the natural range was needed. In 1994, a more extensive seed collection was performed, where seeds from over 500 parent trees were collected from the six main populations of Fraser fir (McKeand et al., 1995). From 1997 to 2000, seedlings were grown from the seed collected in 1994 to establish a provenance-progeny test series at eight field sites in 2000 . The 1983 progeny test series had not included the Grandfather Mountain seed source, and it had included trees from only one elevation class within one mountain in the Balsam Mountains source. In addition, there was a more extensive sampling of the Great Smoky Mountain seed source for this study; 10 areas were included as opposed to just one mountain in the prior study. The objectives of this study were to determine genetic variation among six seed sources of Fraser fir and to estimate genetic parameters for traits important in Christmas tree production, using data collected from this more recent provenance-progeny test series.

\section{Materials and Methods}

Seedlings were grown from open-pollinated seed collected during the 1994 rangewide cone collection. Progeny from 188 of these trees from the following six seed sources were included in this study: the Balsam Mountains, Grandfather Mountain, the Great Smoky Mountains, the Black Mountains, Mount Rogers, and Roan Mountain (Fig. 1). The elevational ranges sampled from each source are shown in Table 1 .

Seeds were cold stratified from February until mid-April of 1997, and then sown into fine vermiculite in a greenhouse in Raleigh, NC. Germinated seeds were transplanted into a 1:1 mixture of peat and perlite in Ray Leach Pine Cells $\left(66 \mathrm{~cm}^{3}\right)$. The greenhouse design was four randomized blocks, each having as many as 51 germinants per seedlot. In Mar. 1998 , the seedlings were transported to the Linville River Nursery near Crossnore, NC, where in June 1998, they were transplanted into fumigated nursery beds. The seedlings for each family were planted in multiple sixtree rows within a family plot across the nursery bed at $15 \times 15 \mathrm{~cm}$ spacing. The greenhouse design of four randomized blocks with as many as 51 trees per plot was kept. The seedlings were maintained in the nursery operated by the North Carolina Division of Forest Resources, using operational Fraser fir nursery practices, including irrigation, fertilization, weed control, and pesticide application. 
In the spring of 2000 , seedlings were transplanted from the nursery beds to field trials. Progeny tests were established at eight locations in the mountains of western North Carolina, testing a total of 188 open-pollinated families. Site characteristics for each test are shown in Table 2. The families from each seed source were divided equally into two groups, with each group of families being tested at four of the eight sites, resulting in two trial series. In each group, the number of families per seed source ranged from 12 to 26. A randomized complete block design was used at each site, with 35 replications of single-tree-plots per family. The seedlings were randomly assigned from the nursery blocks to the field tests. A total of 28,800 trees were planted in the field trials, which included checklots that were not analyzed here. When enough seedlings per family were not available for all replications, another family was randomly substituted for it. The progeny test sites were located on working Christmas tree plantations and were each managed individually by the landowner according to their standard practices. This meant that each site was managed differently with respect to groundcover, pesticide applications, fertilization, and shearing. At all of the sites, shearing began during the fourth year in the field on trees of sufficient size, and was done before the Year 4 measurements were taken. This is a standard practice for Christmas tree production, which involved cutting the terminal shoot as well as trimming the sides to increase the density and enhance the tree's conical shape (Chapman and Wray, 1989; Nichols, 1991). In this first year of shearing, only the tallest of the trees were sheared, a total of 4010 of the test trees $(\approx 18 \%)$.

The following traits were measured each year for the first four seasons in the field: height, number of leaders, overall tree quality, number of lateral buds on current year's leader growth, number of whorl buds on the current terminal, number of lateral branches on previous year's leader growth, and number of whorl branches for the previous year. The quality measurement was an overall subjective rating of the quality of the individual as a Christmas tree, integrating tree density, shape, and overall symmetry without regard to height. This rating was given on a scale of 1 to 5 , with 1 being poor, 3 being average, and 5 being excellent Christmas tree quality. Marketable trees are given a USDA grade, but because these trees were not at market age, this measure of quality was used instead. The number of lateral buds per centimeter of leader length was calculated by dividing the number of lateral buds by the difference between the current and previous year's height measurements. The bud and branch measurements were taken only on a sub-sample: one-third of the families at four of the sites (Alleghany, Ashe, Jackson, and Watauga Counties). The sites in Alleghany and Watauga counties were in group A, and the sites in Ashe and Jackson counties were in group $B$.

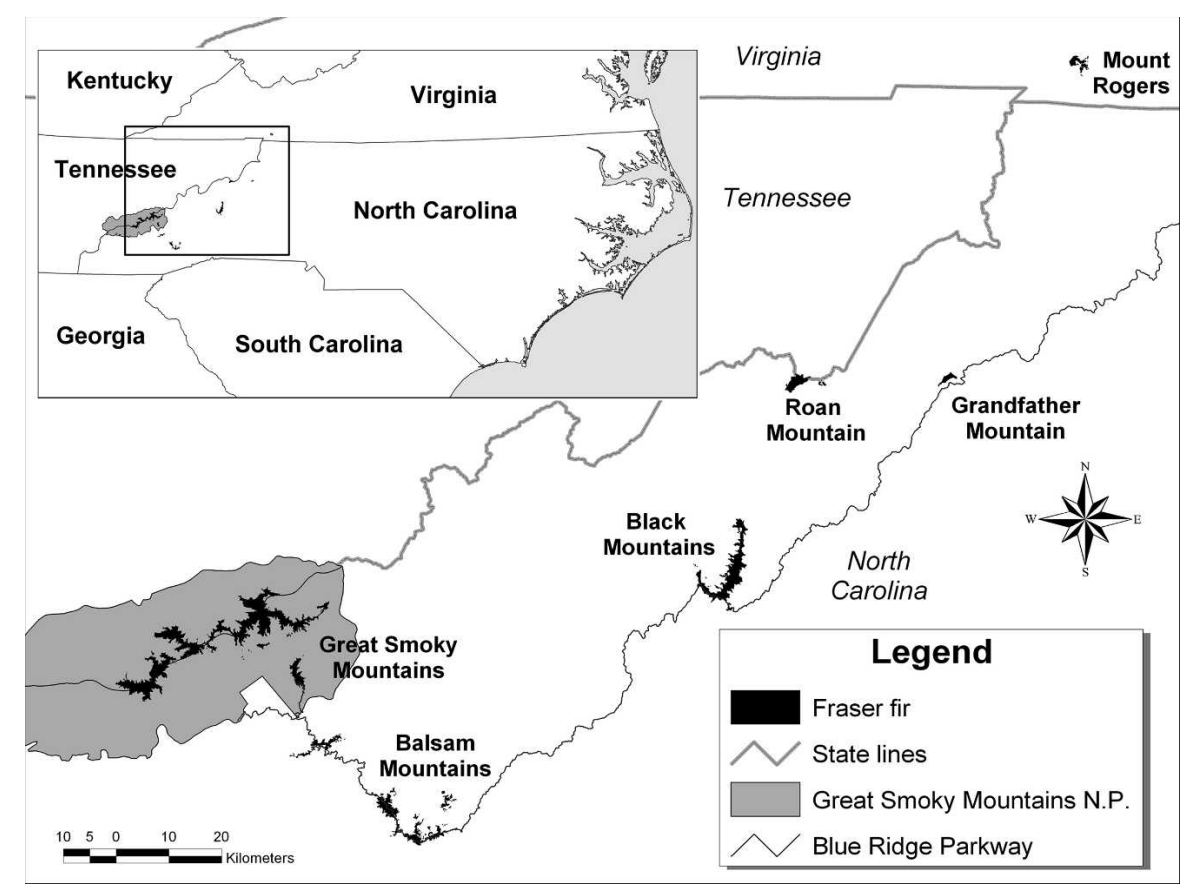

Fig. 1. Map of the natural range of Fraser fir (map by Kevin Potter).

Table 1. Elevational range of Fraser fir populations sampled compared with the population's maximum elevation and the total size of spruce-fir forest type (Dull et al., 1988).

\begin{tabular}{lcccr}
\hline Source & $\begin{array}{c}\text { No. of } \\
\text { families }\end{array}$ & $\begin{array}{c}\text { Elev. range } \\
\text { sampled (m) }\end{array}$ & $\begin{array}{c}\text { Population max. } \\
\text { elev. (m) }\end{array}$ & $\begin{array}{r}\text { Population } \\
\text { size (ha) }\end{array}$ \\
\hline Balsam Mtns. & 36 & $1,512-1,871$ & 1,954 & 2,267 \\
Black Mtns. & 24 & $1,591-1,859$ & 2,037 & 2,922 \\
Grandfather Mtn. & 32 & $1,457-1,609$ & 1,818 & 376 \\
Great Smoky Mtns. & $50^{z}$ & $1,487-1,998$ & 2,025 & 19,717 \\
Roan Mtn. & 26 & $1,676-1,743$ & 1,916 & 688 \\
Mt. Rogers & 24 & $1,524-1,658$ & 1,746 & 640 \\
\hline
\end{tabular}

${ }^{2}$ One family from this source was used in both group A and group B.

Table 2. Site characteristics for the eight test locations of the Fraser fir progeny test series. ${ }^{2}$

\begin{tabular}{|c|c|c|c|c|}
\hline Test location & Group & $\begin{array}{l}\text { Elevation } \\
\quad(\mathrm{m})\end{array}$ & Aspect & Soil type \\
\hline Alleghany County & $\mathrm{A}$ & 1,055 & NW & Porters loam, $10 \%-25 \%$ slopes \\
\hline Ashe County & B & 908 & SE & Watauga loam, $8 \%-15 \%$ slopes \\
\hline Avery County & B & 1,170 & Ridgetop & $\begin{array}{l}\text { Porters gravelly loam, } 15 \%-30 \% \\
\text { slopes, stony }\end{array}$ \\
\hline Jackson County & B & 1,255 & NNW & $\begin{array}{l}\text { Cleveland-Chestnut-Rock outcrop } \\
\text { complex, windswept, } 30 \%-50 \% \text { slopes }\end{array}$ \\
\hline Madison County & A & 744 & NW & $\begin{array}{l}\text { Tusquitee-Whiteside complex, } \\
8 \%-15 \% \text { slopes }\end{array}$ \\
\hline Mitchell County & A & 1,097 & SW & Saunook silt loam, $2 \%-8 \%$ slopes \\
\hline Watauga County & A & 1,219 & SSW & Porters loam, $15 \%-30 \%$ slopes, stony \\
\hline Yancey County & B & 957 & Level & Chandler-Micaville complex, stony \\
\hline
\end{tabular}

${ }^{2}$ Those test locations with the same group designation tested the same families from each source.

Statistical analysis. The linear model for the field analysis incorporated the following effects: group; seed source; group $\times$ source interaction; site(group); source $\times$ site(group) interaction; family[group(source)]; family[group(source)] $\times$ site(group) interaction; and replication[site(group)]. All effects were considered random except for group and seed source. Seed source was considered fixed here because all Fraser fir seed sources were included in the study. The general linear model (GLM) procedure in SAS (SAS Institute, Inc., 2003) was used to perform an analysis of variance on individual tree values. The lsmeans option in the general linear model was used to calculate least-squared means of all the traits for each family. The variance components of random effects were estimated by the restricted maximum likelihood method (REML) in the variance component procedure (VARCOMP) in SAS (SAS Institute, Inc., 2003).

Narrow-sense individual-tree within population heritabilities $\left(\mathrm{h}^{2} \mathrm{i}(\mathrm{p})\right.$ ) were calculated for all traits in Year 4, and for height each year in the field using Eq. [1]:

$\mathrm{h}^{2}{ }_{\mathrm{i}(\mathrm{p})}=4 \sigma_{\mathrm{f}(\mathrm{g}(\mathrm{s}))}^{2} /\left(\sigma_{\mathrm{f}(\mathrm{g}(\mathrm{s}))}^{2}+\sigma_{\mathrm{f}(\mathrm{g}(\mathrm{s})) * \operatorname{site}(\mathrm{g})}^{2}+\sigma_{\mathrm{e}}^{2}\right)$

where $\sigma_{\mathrm{f}[\mathrm{g}(\mathrm{s})]}^{2}$ is the variance due to family[group(source)] differences, $\sigma_{\mathrm{f}[\mathrm{g}(\mathrm{s})]^{*}{ }^{*} \text { site(g) }}$ is 
the variance due to family[group(source) $\times$ site(group) interaction, and $\sigma^{2}{ }_{\mathrm{e}}$ is the error variance (Falconer, 1989).

A reduced linear model incorporating the following effects was also used to analyze each source separately, as well as to calculate narrow sense heritabilities across the breeding population as a whole: group; site(group); family(group); family(group) $\times$ site(group) interaction; and replication(site(group)). As in the full model, all effects were considered random except for group and the variance components of random effects were estimated by the restricted maximum likelihood method (REML) in the variance component procedure (VARCOMP) in SAS (SAS Institute, Inc., 2003). Narrow-sense individualtree heritabilities $\left(\mathrm{h}^{2}\right)$ for all traits in Year 4 as well as Year 4 height for each source separately were calculated using Eq. [2]:

$\mathrm{h}^{2}{ }_{\mathrm{i}}=4 \sigma_{\mathrm{f}(\mathrm{g})}^{2} /\left(\sigma_{\mathrm{f}(\mathrm{g})}^{2}+\sigma_{\mathrm{f}(\mathrm{g})}^{2} *_{\text {site }(\mathrm{g})}+\sigma_{\mathrm{e}}^{2}\right)[2]$ [2]

where $\sigma_{\mathrm{f}(\mathrm{g})}^{2}$ is the variance due to family(group) differences, $\sigma_{\mathrm{f}(\mathrm{g}) * \text { site(g) }}^{2}$ is the variance due to family (group) $\times$ site (group) interaction, and $\sigma^{2}$ is the error variance (Falconer, 1989).

For all analyses, trees that had been damaged that year were excluded. Types of damaged or unhealthy trees that were excluded were those with dead tops or no growth that year, aborted or dead terminal buds, a branch growing as the terminal, flat trees with many leaders, and mowed or deer browsed trees. A large number of trees were damaged by a late frost in Year 3, and trees that had lost their leader due to frost damage were also excluded from the analysis of that year's measurements, but most had recovered and were included in the analysis of traits in Year 4. A thorough analysis of this frost damage and family differences to damage was done by Emerson et al. (2006). This meant that a different number of trees were included for each year; as an example, 19,418 trees were included in the analysis for Year 4. Of the individuals that were excluded from the Year 4 analysis, $\approx 60 \%$ were dead, $34 \%$ had a lateral branch growing as a terminal but had not been sheared, $2.5 \%$ had a dead top with no current growth, and another $\approx 2.5 \%$ had been mowed. To assess the impact of shearing, the heritability estimates for height in Years 3 and 4 were conducted both including and excluding trees that had been sheared during year four. The remainder of the analyses included both sheared and nonsheared trees.

In a separate analysis, Shukla's (1972) stability variance $\left(\sigma^{2}\right)$ was calculated for each source to identify any sources showing instability across the eight sites for height growth after 4 years. Large stability variance values show instability, and unstable sources are those that change rank at different sites or show a change in the size of the differences between sources from one site to another. These stability variance values were calculated using the SAS program developed by Kang (1985). The sum of squares due to environmental non-additivity (S), or heterogeneity, was removed and the remaining source $\times$ site interaction sum of squares was partitioned out for each source $\left(\mathrm{s}^{2}\right)$ (Shukla, 1972). A probability level of $P \leq 0.05$ was used as the minimum level for determining statistical significance.

A Tukey test among source means was performed using the Tukey option in the general linear model (GLM) procedure in SAS (SAS Institute, Inc., 2003) for Year 4 height at each test site with a 0.05 level of significance. Family mean correlations were calculated for all traits in year four using least-squared means for each family in the correlation (CORR) procedure in SAS (SAS Institute, Inc., 2003).

\section{Results}

Means. Highly significant differences were found among seed sources and families within sources $(P \leq 0.0001)$ for height and tree quality after 4 years in the field (Table 3 ). The seed source mean heights for Year 4 ranged from a high of $114 \mathrm{~cm}$ for the Balsam
Mountains to a low of $99 \mathrm{~cm}$ for Roan Mountain (Table 4). The seed source mean number of lateral buds per centimeter ranged from 0.41 for the Balsam Mountains to 0.52 for Roan Mountain. The Mount Rogers and the Black Mountains seed sources ranked second and third overall, respectively, for height after 4 years in the field (Table 4 ). The range in family means for height in Year 4 within just the Balsam Mountains seed source was $79-135 \mathrm{~cm}$, which was greater than the range in seed source means (Table 4). The number of lateral buds and the number of lateral buds per centimeter of leader length were also significant among sources $(P \leq 0.05$, Table 3$)$. The tallest source, the Balsam Mountains, was the lowest for the number of lateral buds per centimeter of leader length.

Correlations. Highly significant, favorable family mean correlations existed for height, number of lateral buds, and quality at age $4(P \leq 0.0001$, Table 5$)$. In addition, there were significant, favorable correlations between overall quality and lateral buds per centimeter $(P \leq 0.05)$ as well as the number

Table 3. ANOVA $F$ values for Year 4 measurements of the Fraser fir progeny test series.

\begin{tabular}{|c|c|c|c|c|c|c|}
\hline & Height & Lat buds & Buds/cm & $\begin{array}{l}\text { Whorl } \\
\text { buds }\end{array}$ & $\begin{array}{l}\text { \% buds } \\
\text { becoming } \\
\text { branches }\end{array}$ & Quality \\
\hline Group & $6.61 *$ & 0.89 & 1.02 & 0.13 & $19.36^{*}$ & 0.85 \\
\hline Source & $7.55 * * *$ & $2.72 *$ & $3.04 *$ & 1.75 & 0.93 & $6.35 * * *$ \\
\hline Group $\times$ source & 1.69 & 1.98 & 0.66 & 0.44 & 1.54 & 2.23 \\
\hline Site(group) & $36.03 * * *$ & $82.89 * * *$ & $8.15^{* *}$ & $27.23 * * *$ & 2.37 & $61.12 * * *$ \\
\hline Source $\times$ site $($ group $)$ & $2.31 * * *$ & 0.60 & 1.04 & 0.73 & 0.95 & 0.99 \\
\hline Family $($ group $\times$ source $)$ & $8.41 * * *$ & $2.74 * *$ & 1.07 & $1.73 *$ & 1.00 & $3.56 * * *$ \\
\hline \multicolumn{7}{|l|}{ Site $\times$ family $($ group $\times$} \\
\hline source) & $1.50 * * *$ & $1.56 * *$ & 1.19 & $1.64 * *$ & 1.00 & $1.29 * * *$ \\
\hline Rep[site(group)] & $9.80 * * *$ & $3.49 * * *$ & 1.01 & $1.63 * * *$ & $1.34 * *$ & $4.89 * * *$ \\
\hline
\end{tabular}

$*, * *, * * *$ Significant at $P \leq 0.05,0.01$, or 0.0001 , respectively.

Table 4. Fraser fir seed source heritabilities (narrow-sense), mean, and range of family means for height at 4 years, ${ }^{\mathrm{z}}$ as well as means for seed source quality and number of lateral buds.

\begin{tabular}{|c|c|c|c|c|c|}
\hline \multirow[b]{2}{*}{ Source } & \multicolumn{3}{|c|}{ Height } & \multirow{2}{*}{$\begin{array}{c}\begin{array}{c}\text { Quality } \\
\text { rating }\end{array} \\
\text { Mean (SD) }\end{array}$} & \multirow{2}{*}{$\begin{array}{c}\text { No. of } \\
\text { lateral buds } \\
\text { Mean (SD) }\end{array}$} \\
\hline & $\begin{array}{l}\text { Heritability } \\
\text { (SE) }\end{array}$ & $\begin{array}{l}\text { Mean (SD) } \\
\text { (in cm) }\end{array}$ & $\begin{array}{l}\text { Range in family } \\
\text { means (in } \mathrm{cm} \text { ) }\end{array}$ & & \\
\hline Balsam & $0.45(0.112)$ & $114(33.7)$ & $79-135$ & $3.0(0.84)$ & $14.1(8.25)$ \\
\hline Rogers & $0.30(0.0961)$ & $108(30.4)$ & $86-128$ & $3.1(0.81)$ & $15.4(8.0)$ \\
\hline Black & $0.16(0.0631)$ & $106(30.4)$ & $84-121$ & $3.1(0.82)$ & $14.4(8.4)$ \\
\hline Grandfather & $0.25(0.0739)$ & $103(30.8)$ & $83-119$ & $3.0(0.82)$ & $14.7(7.6)$ \\
\hline Great Smoky & $0.68(0.140)$ & $103(32.7)$ & $76-136$ & $2.9(0.82)$ & $13.5(7.7)$ \\
\hline Roan & $0.55(0.150)$ & $99(31.7)$ & $74-128$ & $3.1(0.85)$ & $15.5(7.8)$ \\
\hline
\end{tabular}

${ }^{\mathrm{z}}$ Sources are ordered from tallest to shortest mean height.

Table 5. Family mean correlations (upper value) and probability $|r|>0$ (lower value) for traits in Year 4 of the Fraser fir progeny test series.

\begin{tabular}{lccccc}
\hline & No. of & Lateral buds \\
per cm & $\begin{array}{c}\text { \% of buds } \\
\text { becoming } \\
\text { branches }\end{array}$ & $\begin{array}{c}\text { No. of } \\
\text { whorl buds }\end{array}$ & $\begin{array}{c}\text { Quality } \\
\text { rating }\end{array}$ \\
\hline Height & $\mathbf{0 . 6 7}$ & 0.0044 & $-\mathbf{0 . 5 5}$ & -0.25 & $\mathbf{0 . 6 4}$ \\
& $<\mathbf{0 . 0 0 0 1}$ & 0.97 & $<\mathbf{0 . 0 0 0 1}$ & 0.061 & $<\mathbf{0 . 0 0 0 1}$ \\
No. of lateral buds & & $\mathbf{0 . 5 4}$ & $-\mathbf{0 . 4 9}$ & 0.10 & $\mathbf{0 . 6 8}$ \\
& & $<\mathbf{0 . 0 0 0 1}$ & $<\mathbf{0 . 0 0 0 1}$ & 0.43 & $<\mathbf{0 . 0 0 0 1}$ \\
Lateral buds per cm & & $-\mathbf{0 . 2 6}$ & 0.20 & $\mathbf{0 . 4 0}$ \\
\% buds becoming & & $\mathbf{0 . 0 4 7}$ & 0.13 & $\mathbf{0 . 0 0 1 5}$ \\
branches & & & -0.085 & $\mathbf{- 0 . 3 9}$ \\
No. of whorl buds & & & 0.52 & $\mathbf{0 . 0 0 2 1}$ \\
& & & & 0.14 \\
\hline
\end{tabular}

Correlations significant at $P \leq 0.05$ are shown in bold. 
of lateral buds in Year 4 ( $P \leq 0.0001$, Table $5)$. A highly significant, unfavorable correlation existed between height and the percent of buds becoming branches $(P \leq 0.0001$, Table 5).

Source by site interaction. Highly significant seed source $\times$ site interactions as well as height in Year $4(P \leq 0.0001)$. There were some rank changes for average seed source height across sites (Table 6). Shukla's (1972) stability variance analysis showed that two of the six seed sources had significant instability across the test sites; the sources showing instability were the Balsam Mountains and Roan Mountain. Tukey test results showed that at three of the test sites, Roan Mountain had a significantly lower mean Year 4 height than the other seed sources (Table 6). At the top-ranked for height, the Alleghany test site, its mean was not significantly lower than that of the first-ranked source (Table 6). When the Avery County site was removed and Shukla's stability variance analysis was performed, the Balsam Mountains source no longer showed significant instability.

Heritability. The heritability values for the traits measured in Year 4 varied greatly, from 0 to 0.44 (Table 7). The standard deviations for these values were relatively low, due to the large sample size and good test precision. The heritability for the percent of lateral buds becoming branches was 0 , and neither seed source nor family within source were significant for this trait. The number of lateral buds had a modest heritability value of 0.17 . The heritability for the number of lateral buds did not change greatly when family (source) $\times$ site interactions existed for one site where the Balsam Mountains was not

calculated including or excluding the trees that had been sheared; the heritability values in Year 4 were 0.17 and 0.19 , with and without the sheared trees included, respectively. The number of lateral buds per centimeter leader length and the number of whorl buds both had low heritability values $(0.01$ and 0.080 , respectively). The overall tree quality trait had a low heritability of 0.14 , and the seed source mean tree quality values only varied from 2.91 for the Great Smoky Mountains to 3.11 for Mount Rogers.

When the sheared trees were left out of the calculation, the heritability value for height in Year 4 decreased from 0.44 to 0.40 . In the Year 3 measurements, before any shearing had begun, the heritability values for height were also calculated with and without the trees sheared in Year 4 included. Again, the heritability value for height was lower when the sheared trees were excluded, but a greater difference was seen; the heritability values for height in Year 3 were 0.39 and 0.30 with and without including the trees that were sheared the following year, respectively.

Heritability values for height decreased each year from Year 1 to Year 3 and then increased from Year 3 to Year 4 (Table 8). Heritability values for height at age 4 varied greatly among the six sources, from 0.16 for the Black Mountains to 0.68 for the Great Smoky Mountains (Table 4). In addition, if the Black Mountains seed source was excluded, there was somewhat of a trend of increasing heritability for height at age 4 with increasing population size of the seed source as well as with increasing mean elevation sampled (Tables 1 and 4). The Balsam Mountains seed source had the highest aver-

Table 6. Average height $(\mathrm{cm})$ in Year 4 by seed source at each site, with group A or B indicated for each site in parentheses. $^{\mathrm{z}}$

\begin{tabular}{lrrrrrrr}
\hline & Site & & \multicolumn{5}{c}{ Great } \\
Site & mean & Balsam & Rogers & Black & Smoky & Grandfather & Roan \\
\hline Jackson (B) & $120 \mathrm{a}$ & $126(1) \mathrm{a}$ & $124(2) \mathrm{a}$ & $118(3) \mathrm{b}$ & $117(5) \mathrm{b}$ & $118(4) \mathrm{b}$ & $117(6) \mathrm{b}$ \\
Yancey (B) & $119 \mathrm{a}$ & $126(1) \mathrm{a}$ & $119(2) \mathrm{b}$ & $118(3) \mathrm{bc}$ & $115(6) \mathrm{c}$ & $116(5) \mathrm{bc}$ & $117(4) \mathrm{bc}$ \\
Avery (B) & $118 \mathrm{a}$ & $132(1) \mathrm{a}$ & $117(2) \mathrm{b}$ & $115(4) \mathrm{b}$ & $117(3) \mathrm{b}$ & $111(6) \mathrm{b}$ & $113(5) \mathrm{b}$ \\
Mitchell (A) & $108 \mathrm{~b}$ & $118(1) \mathrm{a}$ & $110(3) \mathrm{b}$ & $111(2) \mathrm{b}$ & $104(5) \mathrm{c}$ & $107(4) \mathrm{bc}$ & $97(6) \mathrm{d}$ \\
Ashe (B) & $105 \mathrm{~b}$ & $116(1) \mathrm{a}$ & $108(2) \mathrm{b}$ & $103(3) \mathrm{c}$ & $103(4) \mathrm{c}$ & $100(6) \mathrm{c}$ & $102(5) \mathrm{c}$ \\
Madison (A) & $103 \mathrm{c}$ & $112(1) \mathrm{a}$ & $105(3) \mathrm{ab}$ & $106(2) \mathrm{ab}$ & $103(4) \mathrm{b}$ & $101(5) \mathrm{b}$ & $87(6) \mathrm{c}$ \\
Alleghany (A) & $93 \mathrm{~d}$ & $99(2) \mathrm{a}$ & $96(3) \mathrm{ab}$ & $99(1) \mathrm{a}$ & $92(5) \mathrm{c}$ & $92(4) \mathrm{bc}$ & $85(6) \mathrm{d}$ \\
Watauga (A) & $77 \mathrm{e}$ & $81(1) \mathrm{a}$ & $80(2) \mathrm{a}$ & $80(3) \mathrm{a}$ & $74(5) \mathrm{bc}$ & $78(4) \mathrm{ab}$ & $70(6) \mathrm{c}$ \\
\hline
\end{tabular}

${ }^{\text {z}}$ Seed source rank at each site is in parentheses, and the Tukey grouping for each row is shown on the right side. Sources are ordered by decreasing height. age height value at seven out of the eight sites but not the highest heritability value. The Black Mountains and Mount Rogers, the other two top-performing sources, had low heritabilities for height.

Heritability values across the entire breeding population were also calculated for the Year 4 traits. These heritability values were slightly higher than the individual within population heritabilities but showed the same overall trends (Table 7).

\section{Discussion}

The highly significant seed source differences demonstrated the importance of seed source selection in Fraser fir for Christmas tree production, and the highly significant family differences and large range in family means indicated that family within source selection is also extremely important. If selections were made at age 4 , the topperforming source for height was the Balsam Mountains. This agrees with previous results both at age 4 and age 8 from the one mountain tested from this source in the earlier study (Arnold and Jett, 1995; Arnold et al., 1994b; Jett et al., 1993). The market value of Christmas trees is based on height and quality of the tree. A one-foot increase in tree height at harvest time can add about $\$ 3$ to $\$ 5$ to the value of trees in the most popular height classes. Therefore, the difference of $15 \mathrm{~cm}$ between the means for the tallest and shortest average sources after just 4 years of growth in the field can amount to significant differences in value at rotation age. The previous Fraser fir progeny test study also showed a high correlation among early age height and rotation age height class, USDA grade, and wholesale value, indicating that early age selection can be done successfully in Fraser fir (Arnold and Jett 1995; Arnold et al., 1994a, 1994b).

The number of lateral buds and number of lateral buds per centimeter of leader length are important traits because they affect the crown density of the tree, which is a factor in determining USDA grade. It has been shown that greater numbers of buds on the main stem of the tree were associated with trees having higher USDA grades (Hockman et al., 1990). In the previous study, estimates of crown density at age 4 and age 8 were

Table 7. Heritability and variance component estimates for Fraser fir traits in Year 4.

\begin{tabular}{|c|c|c|c|c|c|c|}
\hline & $\begin{array}{l}\text { Height } \\
(\mathrm{cm})\end{array}$ & $\begin{array}{l}\text { No. of lateral } \\
\text { buds }\end{array}$ & $\begin{array}{l}\text { Lateral buds } \\
\text { per } \mathrm{cm}\end{array}$ & $\begin{array}{c}\% \text { of buds becoming } \\
\text { branches }\end{array}$ & $\begin{array}{c}\text { No. of } \\
\text { whorl buds }\end{array}$ & $\begin{array}{l}\text { Quality } \\
\text { rating }\end{array}$ \\
\hline$\overline{\operatorname{Var}[\operatorname{site}(\text { group})]}$ & 101.3 & 14.5 & 0.00200 & 0.00256 & 0.0574 & 0.0660 \\
\hline Var[family (group $\times$ source $)]$ & 82.6 & 2.2 & 0.000410 & 0 & 0.0244 & 0.0205 \\
\hline $\operatorname{Var}[$ source $\times$ site $($ group $)]$ & 3.2 & 0 & $2.43 \mathrm{E}-05$ & 0 & 0 & 0 \\
\hline \multicolumn{7}{|l|}{ Var[site $\times$ family } \\
\hline$($ group $\times$ source $)]$ & 12.4 & 0.7 & 0.00128 & 0 & 0.0200 & 0.00660 \\
\hline $\operatorname{Var}[\operatorname{rep}($ group $\times$ site $)]$ & 93.2 & 4.3 & 0.000290 & 0.0114 & 0.0269 & 0.0348 \\
\hline Var(error) & 651.9 & 47.0 & 0.181 & 0.869 & 1.178 & 0.571 \\
\hline Heritability (within population) & 0.44 & 0.17 & 0.0090 & 0 & 0.080 & 0.14 \\
\hline Standard error of heritability & 0.0488 & 0.0547 & 0.0225 & 0 & 0.0388 & 0.0201 \\
\hline Mean & 105 & 14.63 & 0.47 & 1.18 & 3.64 & 3.01 \\
\hline Standard deviation of the mean & 32.1 & 8.01 & 0.43 & 0.95 & 1.13 & 0.83 \\
\hline Heritability (across populations) & 0.53 & 0.20 & 0.033 & 0 & 0.081 & 0.17 \\
\hline Standard error of heritability & 0.0542 & 0.0550 & 0.0242 & 0 & 0.0363 & 0.0228 \\
\hline
\end{tabular}


Table 8 . Individual within-population heritability for height for all 4 years in the field with standard error (SE) in parentheses.

\begin{tabular}{lc}
\hline Yr & Heritability \\
\hline 2000 & $0.67(0.0678)$ \\
2001 & $0.52(0.0562)$ \\
2002 & $0.39(0.0463)$ \\
2003 & $0.44(0.0488)$ \\
\hline
\end{tabular}

significantly different among sources for Fraser fir (Arnold and Jett, 1995; Arnold et al., 1994b; Jett et al., 1993). This agrees with the results here where both the number of lateral buds and the number of lateral buds per centimeter of leader length were significantly different among sources. The mean number of lateral buds ranged from 13.5 for the Great Smoky Mountains to 15.5 for Mount Rogers, and the mean number of lateral buds per centimeter leader length ranged from 0.41 for the Balsam Mountains to 0.52 for Roan Mountain. There appears to be somewhat of a gradient from north to south for the number of lateral buds, where the more southern sources tended to have a lower mean number of lateral buds. It is of some concern that the Balsam Mountains source, which is the tallest source, had the lowest average number of lateral buds per centimeter of leader length, because this may indicate that it has a lower crown density. But family selection within source could overcome any lower bud production in the Balsam Mountains source because there is a positive family mean correlation between height and the number of lateral buds and no correlation with bud density. In a study by Arnold et al. (1994b), although crown density showed strong favorable genetic correlations with wholesale value, the strongest correlation with wholesale value was for height class. In this prior study, the Richland Balsam source had the greatest average wholesale value and the lowest average density score, which was scored on a scale of 1 to 3 (Arnold and Jett, 1995; Arnold et al., 1994b). It is likely that the Balsam Mountains seed source tested here may still have the greatest wholesale value because of its greater height growth and despite its lower bud production. Height is a more important factor than crown density in determining Christmas tree wholesale value, and the range in bud production among sources was not very large.

Overall, the Black Mountains seed source ranked average for height after 4 years in the field. In the 1983 progeny test series, similar results were seen for the Mount Mitchell seed source from the Black Mountains, tested from $1829 \mathrm{~m}$ (6000-feet elevation class), where it ranked fifth out of nine provenance/elevation classes for height and wholesale value after 8 years in the field (Arnold and Jett, 1995; Arnold et al., 1994b). The Mount Mitchell source from $1981 \mathrm{~m}$ (6500-feet elevation class) performed very poorly for height in this prior progeny test series, ranking lowest of the nine sources tested for height and wholesale value after 8 years in the field, but this was the only source tested from elevations this high (Arnold and Jett 1995; Arnold et al., 1994b). Perhaps the Black Mountains seed source height was better in the present study because seed from the higher elevations were not sampled; only an elevational range of 1591 to $1859 \mathrm{~m}$ was included. Height growth for many individuals was affected by the late spring frost in Year 3. But because there were very highly significant correlations between Year 4 height of frost-damaged and non-frostdamaged individuals, it is not believed that the frost damage has greatly affected the Year 4 analysis (Emerson et al., 2006).

Correlations. The highly significant, favorable family-mean correlations indicate that if selections are made based on height, this will also indirectly select for a higher overall tree quality and a greater number of lateral buds. Therefore, selections can probably be made based mainly on height, which was also recommended based on results from the prior Fraser fir progeny test series (Arnold et al., 1994a, 1994b). The number of lateral buds is one indication of crown density, so a favorable correlation of this trait with height is very beneficial for breeders. The significant, unfavorable correlation between height and the percent of buds becoming branches may be due to varying allocation of resources; if more resources are allocated to height growth, there are less available resources for branch growth.

Source by site interaction. Even though the top-performing source for height, Balsam Mountains, was unstable, this should not be of much concern to breeders, since it was still ranked first for height at seven out of eight sites (Table 6). At the one test site where the Balsam Mountains source was ranked second, its mean height was still within $0.5 \mathrm{~cm}$ of, and not significantly different from, the mean height for the source ranked first. Most of the instability for the Balsam Mountains source seems to be due to the Avery County site, because it no longer showed instability when this site was removed from the analysis. There was a high percentage of mortality at this test site from phytophthora root rot (caused by Phytophthora cinnamomi Rands), and this may have affected the source mean heights. The site effects include not only environmental effects but also differences in management. A different cultural technique was used at the Avery County site, where the whorl buds were removed and the terminal branch was not cut back as performed at the other sites. This is a nontraditional technique that allows the lateral branches to fill in, without sacrificing height growth of the tree. This allowed the Balsam Mountain seed source to better express its height growth potential at this site. In addition, the instability of Roan Mountain should not be a concern to breeders because it was still a relatively poor performer for height across all sites, limiting its use in breeding programs. Thus, the source by site interactions do not seem to be of practical importance, and there was still strong consistency seen across the test sites.

Heritability. The heritability for traits in year four were calculated in two ways; the within-population heritability used a model that included source, whereas the acrosspopulation heritability did not use source in the model and was therefore a measure of the heritability across the entire breeding population. A multiplier of 4 was used in the heritability calculations. Although no studies of inbreeding in Fraser fir have been done, another multiplier, such as 3 , may be more appropriate with inbreeding, which would reduce the heritability estimates. For all traits, the across-population heritability was slightly higher than the within-population heritability, which was expected. For Year 4 height, the within-population heritability was 0.44 and the across-population heritability was 0.53 . All further heritability values in this discussion are the within-population heritabilities.

Height had the highest heritability value of all the traits measured (0.44), indicating that important genetic gains can be achieved from selection and breeding of Fraser fir. This is especially promising for Christmas tree breeders because height is of great importance in determining Christmas tree value. The percent of lateral buds becoming branches appeared to be mainly controlled by environmental conditions, so its significant unfavorable correlation with height is not of importance for breeding programs. The small range in means and low heritability for the overall quality trait suggest that it is not a trait that would benefit much from selection and breeding.

Shearing of the trees, including leader length reduction, was done for the first time before the fourth year's measurements were taken, and only the tallest trees were sheared at this time. We expected that the practice of shearing would make the trees phenotypically more uniform, and it was expected that this would cause the heritability value for height to decrease. However, because the heritability for height at age 3 years (before shearing) was lower when the sheared trees were eliminated $(0.30$ excluding sheared trees vs. 0.39 including sheared trees), the sheared trees were included in all data analyses at age 4 years. This increase in heritability was probably due to the larger sample size $(19,418$ vs. 15,408$)$ by including all the trees in the analysis and because only the largest trees were sheared. It is predicted that the heritability value with the sheared trees included is closer to what the heritability value would have been had they not been sheared $(0.40$ excluding sheared trees vs. 0.44 including sheared trees)

The decrease in heritability values for height each year from Year 1 to Year 3 and an increase from Year 3 to Year 4 is not the trend that was expected. In a prior study with Fraser fir, heritability values for height increased both from Year 0 to Year 1 and from Year 1 to Year 4, then decreased from Year 4 to Year 8 (Arnold et al., 1994b). One reason for the results seen here is that the heritability value for Year 3 was most likely lower than it would have been because of the frost damage occurring that spring. Some 
damage occurred at all sites, and at two of the sites, a great majority of the trees were damaged by frost in Year 3 (Emerson et al., 2006). Often this damage was to the terminal leader, which affected total height. Then, in Year 4, the larger trees were sheared, again perhaps lowering the heritability. This effect from shearing was seen in the prior study with Fraser fir, where shearing began after Year 4, and heritability for height decreased from Year 4 to Year 8 (Arnold et al., 1994b). In the current study, heritability did decrease from Year 2 to Year 4, in part due to the shearing. In addition, the heritability for height at age 1 may have been higher than expected because the buds for that year's growth were set in the nursery where environmental variation was lower.

When comparing the heritability values for height across the six seed sources, the topperforming sources for height did not have the greatest heritability values. Because more selections will be made from the top-performing sources, it would be preferable if these top-performing seed sources also had higher heritability values for the more important traits. The Black Mountains seed source had the lowest heritability for height in Year 4 , and the mean elevation tested from the Black Mountains was $1723 \mathrm{~m}$. A low heritability of 0.06 was seen in the previous progeny test series for Mount Mitchell in the Black Mountains from the 1800-m elevation class for height at age 8 (Arnold et al., 1994b). One possible reason for the low heritability seen for the Black Mountains is that past logging and subsequent wildfires reduced the population size and decreased genetic diversity (Pyle and Schafale, 1988). In addition, some of the parent trees from the Black Mountains were from areas that had been planted (Pyle and Schafale, 1988). The source of the planted seedlings is unknown and may have been of limited genetic diversity, which would have decreased the heritability. The Grandfather Mountain seed source also had a low heritability for height, which is likely due to its small population size and the fact that many areas of this population were not included in the test. The seed source with the highest heritability for height is the Great Smoky Mountains, which is the largest population of Fraser fir and has the greatest amount of unlogged and unburned Fraser fir stands (Pyle and Schafale, 1988). Only a small percentage of this population had been logged when the Great Smoky Mountains National Park was established, and the area was protected from logging (Pyle and Schafale, 1988).

Selections for future tree improvement and breeding were made from this progeny test series after the fifth year in the field. Based on previous results, selection can be effective in Fraser fir after just four years in the field (Arnold and Jett 1995; Arnold et al., 1994a, 1994b). The decision to delay making selections until after the fifth year in the field was due to the heavy frost damage sustained at some of the sites during the third year. It was believed that by the fifth year in the field, most height losses as a result of this frost damage will have been overcome (or that families and individuals hit hard by frost and not able to recover will not be selected).

The seed source that is currently one of the most commonly used by commercial Christmas tree growers is the Roan Mountain source because it is one of only two sources readily available for commercial seed collection. Roan Mountain was the poorest seed source for mean height after 4 years in the field, and similar results were seen in the previous progeny test series where the two elevation classes from Roan Mountain ranked sixth and seventh out of nine sources/ height class combinations for height after 8 years in the field (Arnold and Jett 1995; Arnold et al., 1994b). It would be more profitable to use families from faster-growing sources, although due to the great deal of within source variation, some of the better Roan Mountain families are acceptable. Selections that will be made from the current trial will be valuable to growers and should result in a substantial improvement in quality and value compared with those currently grown for Christmas trees.

In addition to the selections that were made after the fifth year in the field, a final round of selections will be made after the seventh season in the field. All the progeny selected will be preserved in a clone bank for genetic conservation purposes. The best of these selections will be used to expand the Christmas tree growers' current seed orchard. In addition, all the seed collected in the 1994 seed collection has been saved, and seed collections from areas that have not yet been sampled have been and will continue to be sampled to increase the genetic diversity of the seed bank.

\section{Literature Cited}

Arnold, R.J. and J.B. Jett. 1995. Seed source variation for growth and quality traits of Fraser fir Christmas trees: Rotation age results. South. J. Appl. For. 19(4):157-161.

Arnold, R.J., F.E. Bridgwater, and J.B. Jett. 1994a. Single- and multiple-trait index selection efficiencies in Fraser fir Christmas trees. Can. J. For. Res. 24:1487-1494

Arnold, R.J., J.B. Jett, and S.E. McKeand. 1994b. Natural variation and genetic parameters in Fraser fir growth and Christmas tree traits. Can. J. For. Res. 24:1480-1486.

Chapman, A.G. and R.D. Wray. 1989. Christmas trees for pleasure and profit. Rutgers University Press, New Brunswick, NJ.

Dull, C.W., J.D. Ward, H.D. Brown, G.W. Ryan, W.H. Clerke, and R.J. Uhler. 1988. Evaluation of spruce and fir mortality in the Southern Appalachian Mountains. USDA Forest Service, Southern Region, Protection Report R8-PR13, Atlanta, GA. 92 pp.

Emerson, J.L., J. Frampton, and S.E. McKeand. 2006. Genetic variation of spring frost damage in three-year-old Fraser fir Christmas tree plantations. HortScience 41(7):1531-1536.

Falconer, D.S. 1989. Introduction to quantitative genetics. Longman, London.

Hockman, J.N., J.A. Burger, and D.W. Smith. 1990. Classification model to predict Fraser fir Christmas tree grade. For. Sci. 36(1):4553.

Jett, J.B., S.E. McKeand, Y. Liu, and W.T. Huxster. 1993. Seed source variation for height and crown traits of Fraser fir Christmas trees. South. J. Appl. For. 17(1):5-9.

Kang, M.S. 1985. SAS program for calculating stability-variance parameters. J. Hered. 76: 142-143.

McKeand, S., F. Bridgewater, C. McKinley, J.B. Jett, and R. Arnold. 1995. 1994 seed collection from natural stands of Fraser fir and plans for breeding and genetics research at NCSU. Limbs Needles 22(1):4, 6-7.

Mitchell, R.G. 1966. Infestation characteristics of the balsam woolly aphid in the Pacific Northwest. Pacific Northwest For. and Range Expt. Sta., U.S. For. Serv. 18 pp.

Nichols, T.J. 1991. Shearing, p. 79-103. In: J.E. Johnson (ed.). Christmas tree production manual. Virginia Cooperative Extension, Publication 420-075.

Pyle, C. and M.P. Schafale. 1988. Land use history of three spruce-fir forest sites in Southern Appalachia. J. For. History 32:4-21.

SAS Institute, Inc. 2003. SAS/STAT User's guide, version 8 . SAS Institute, Inc., Cary, NC.

Shukla, G.K. 1972. Some statistical aspects of partitioning genotype-environmental components of variability. Heredity 29:237-245.

Speers, C.F. 1958. The balsam woolly aphid in the Southeast. J. For. 56:515-516.

Witter, J.A. and I.R. Ragenovich. 1986. Regeneration of Fraser fir at Mt. Mitchell, North Carolina, after depredations by the balsam woolly adelgid. For. Sci. 32(3):585594. 